УДК: 378.174:001.9

DOI: $\underline{10.35619 / \text { iiu.v2i11.206 }}$

\author{
Никонорова Людмила \\ старший викладач кафедри іноземних мов \\ Національної академії статистики, обліку та аудиту, \\ м. Київ, Україна \\ ORCID: 0000-0003-1848-1714 \\ e-mail: lipotselyi@gmail.com
}

\title{
ІННОВАЦІЙНІ ТЕХНОЛОГІЇ В ОСВІТІ: МЕТОД ПРОЄКТІВ У ВИВЧЕННІ IНОЗЕМНИХ МОВ
}

Анотація. Оскільки нові соціально-економічні умови розвитку світової спільноти спричинили зміну вимог до професійної підготовки фахівців, то перед системою освіти постає проблема якісної підготовки конкурентоспроможних компетентних фахівців нового рівня, зорієнтованих на особистісне самовдосконалення і професійне зростання. Саме тому доцільно актуалізувати метод проєктів як педагогічну технологію, що включає в себе сукупність дослідницьких, пошукових та проблемних методів. Основне завдання цього методу полягає у наданні студентам можливості самостійного набуття знань у процесі вирішення практичних завдань або проблем, що вимагає інтеграції знань 3 різних предметних галузей. У навчанні англійської мови метод проєктів надає можливість студентам використовувати мову в ситуаціях реального повсякденного життя, що сприяє кращому засвоєнню і закріпленню знань з іноземної мови. У статті визначені ключові умови, які доцільно враховувати, плануючи роботу з освітнім проєктом з іноземної мови, а також труднощі, які можуть виникнути під час використання цього методу. 3'ясовано, що проєктна діяльність студентів зорієнтована на розкриття особистості, розвиток інтересу до освітньої діяльності, розвиток інтелектуальних і творчих здібностей у процесі вирішення будь-якої проблеми.

Ключові слова: інновації у закладах вищої освіти, вивчення іноземної мови, інноваційні технології, проєкт, метод проєктів.

Постановка проблеми. У XXI столітті серед актуальних проблем суспільного розвитку вагоме місце займає проблема інновацій, оскільки велика кількість відкриттів, стрімкість розвитку знання і науки вимагає від людини розвиненого дослідного, творчого мислення. Це зумовлює зміну змісту і цілей освіти, найвищою цінністю якої стає освіченість, усвідомлення власної індивідуальності через особистісний досвід. Тому актуальним вважаємо дослідження новітніх технологій в освіті 3 метою вивчення іноземних мов. Проєктний метод навчання забезпечує реалізацію принципу культуровідповідності в гуманітарному освітньому просторі, оскільки дає змогу інтегрувати знання в різних наукових сферах, а також допомагає побудувати процес взаємодії між студентом i викладачем на основі співпраці та педагогічної підтримки розвитку.

Мета статті - дослідити можливості застосування методу проєктів для вивчення іноземних мов в умовах закладу вищої освіти (ЗВО).

Виклад основного матеріалу дослідження. Нові соціально-економічні умови розвитку світової спільноти спричинили зміну вимог до професійної підготовки фахівців, які повинні володіти високою професійною компетенцією, вміти самостійно здобувати нові знання, 
креативно мислити, знаходити оптимальні рішення в нестандартних ситуаціях, мати здібності до інноваційної діяльності. Перед системою освіти постає проблема якісної підготовки конкурентоспроможних компетентних фахівців нового рівня, орієнтованих на особистісне самовдосконалення і професійне зростання.

Перехід на нові освітні стандарти висуває перед ЗВО нові завдання: пошук i впровадження в освітній процес педагогічних технологій, методів, способів навчання, що забезпечують формування конкурентоспроможних фахівців, які відповідають вимогам сучасного ринку праці. Оскільки традиційна система навчання, що грунтується на трансляції готових знань, зводиться до вирішення теоретичних і практичних завдань за заданими алгоритмами і схемами, мало орієнтована на самовдосконалення і саморозвиток студентів, виникає проблема пошуку ефективних напрямів вирішення проблеми якісної підготовки високопрофесійних фахівців нового рівня (Зембатова і Бтемирова, 2008).

Одним $з$ таких методів $є$ метод проєктів, який включає в себе сукупність дослідницьких, пошукових, проблемних методів, творчих за самою своєю суттю (Бтемирова, 2012).

Термін «проєкт» (у перекладі з латинської «projectus») означає «кинутий вперед», а в словниках визначається як план, задум, прототип, прообраз якого-небудь об'єкта, виду діяльності (Комаровский, 1969).

Проєкт, за образним висловом С. Кримського, має здатність до продуктивної реалізації. Проєкт є систематичною формою організації діяльності у взаємозв'язку іiї теоретичних та практичних аспектів (Кримський, 2003).

У педагогічній літературі метод проєктів розглядається в різних аспектах: як метод навчання, як форма навчання, як вид навчальної діяльності, як засіб управління пізнавальною діяльністю, як засіб організації самостійної роботи студентів.

Метод проєктів виник у період перегляду поглядів на систему загальної освіти. Зокрема, в Америці на початку XX ст. гостро постала проблема навчання дітей, які в силу своїх здібностей, інтересів, зайнятості не могли засвоїти необхідний освітній мінімум. У дореволюційній Росії одним 3 джерел методу проєктів можна вважати інтерес до особистості кожного учня, що актуалізувався у той же період. Приміром, Л. М. Толстой, який вивчав теорію вільного виховання Ж.-Ж. Руссо, розглядав виховання як створення умов, що сприяють розвитку особистості дитини. Розвиток у цьому випадку передбачає мимовільне розкриття якостей дитини при обережній ролі вчителя (Комаровский, 1969).

Таке тлумачення поняття виховання сприяло появі нових цілей в освіті. На межі XIX$\mathrm{XX}$ ст. вчені і педагоги замислювалися про нову систему освіти, орієнтовану на учня і його індивідуальні особливості. У цей період поширення набув гуманістичний підхід в освіті й вихованні. Зокрема, прототипом методу проєктів в Америці можна вважати розроблену Д. Дьюї технологію навчання і виховання дітей, за якої в основу навчальної діяльності були покладені п'ять актів мислення (Комаровский, 1969). Американське Бюро виховання запропонувало офіційне вживання терміну «проєкт» у 1911 році. Під «проєктом» Д. Снедзен і його колеги розуміли як основу формування особистості дитини самостійно плановану учнями і регульовану учителем практичну діяльність, яка підпорядковується алгоритму отримання знань.

У вітчизняній дореволюційній педагогіці П. П. Блонський (трудова школа), А. Г. Калашніков (індустріальна школа) та інші вчені-педагоги використовували ідеї проєктного навчання, принципи його побудови для створення шкіл нового типу.

В Україні метод проєктів отримав офіційний статус й небувале поширення у 20-х роках XX ст. 
За радянської влади ідеї проєктного навчання набули широкого поширення, метод проєктів був визнаний таким, що відповідає цілям побудови соціалізму, і оголошений єдиним засобом перетворення школи навчання в школу життя і праці (Новиков і Новиков, 2004). Однак універсалізація цього методу і відмова від систематичного вивчення навчальних предметів поступово призвели до зниження рівня знань в учнів, метод проєктів був визнаний неефективним і вилучений зі шкільної практики.

Сьогодні відбувається нове відродження методу проєктів, яке пов'язують з розвитком технологій комп'ютерної телекомунікації. Проєктна діяльність починає займати важливе місце не тільки в системі загальної, але й вищої освіти, даючи студенту змогу набувати навички, які не набуваються традиційними методами навчання. Багато педагогів вважають метод проєктів одним 3 найефективніших методів розвитку когнітивних i творчих здібностей студентів, формування професійної компетентності.

Метод проєктів - це сукупність прийомів, дій студентів і викладача в їхній певній послідовності для досягнення поставленого завдання - вирішення певної проблеми, значущої для студентів і оформленої у вигляді деякого кінцевого продукту. Основна мета методу проєктів полягає в наданні студентам можливості самостійного набуття знань в процесі вирішення практичних завдань або проблем, що вимагає інтеграції знань з різних предметних галузей.

Якщо говорити про метод проєктів як про педагогічну технологію, то ця технологія передбачає сукупність дослідницьких, пошукових, проблемних методів, творчих за своєю суттю. Викладачу в межах проєкту відводиться роль розробника, координатора, експерта, консультанта.

Популярність методу проєктів забезпечується можливістю поєднання теоретичних знань i їх практичного застосування для вирішення конкретних проблем. Крім того, метод проєктів підтримує становлення нових підходів до організації педагогічного управління, $\epsilon$ одним з ефективних засобів побудови особистісно-орієнтованої педагогічної системи.

Метод проєктів - це комплексний навчальний метод, який дозволяє індивідуалізувати освітній процес, дає можливість студенту проявляти самостійність у плануванні, організації і контролю за своєю діяльністю. Він дає студентам змогу проявити самостійність у виборі теми, джерел інформації, способі її викладу і презентації.

Проєктна методика уможливлює ведення індивідуальної роботи над темою, яка викликає найбільший інтерес у кожного учасника проєкту, що, безсумнівно, формує підвищену мотивовану активність студента.

Аналізуючи педагогічну літературу з проблеми, різні підходи до поняття методу проєктів, можна зробити висновок, що організація проєктної діяльності студентів спрямована на формування навичок самостійного здобуття знань, набуття професійних компетенцій. Тому завданнями проєктної діяльності студентів є:

- систематизація, закріплення, поглиблення набутих теоретичних знань i умінь студентів;

- закріплення і розвиток практичних умінь;

- розвиток пізнавальних, творчих здібностей студентів;

- формування креативного мислення, здібностей до саморозвитку, самовдосконалення.

Іноземна мова - елемент культури, вона функціонує в межах певної культури. Отже, ми повинні бути ознайомлені з особливостями цієї культури та особливостями функціонування іноземної мови в цій культурі. Тобто мова йде про необхідність формування країнознавчої компетенції. Тому у навчанні англійської мови метод проєктів надає можливість студентам використовувати мову в ситуаціях реального повсякденного життя, що, безумовно, сприяє 
кращому засвоєнню і закріпленню знань 3 іноземної мови. Тільки метод проєктів може вирішити ці дидактичні завдання $\mathrm{i}$, відповідно, перетворити заняття 3 іноземної мови в дискусійний, дослідницький клуб, в якому вирішуються дійсно цікаві, практично значущі і доступні для студентів проблеми з урахуванням особливостей культури країни i, при можливості, на основі міжкультурної взаємодії. На таких заняттях з іноземної мови має бути предмет обговорення.

В основі проєкту завжди є певна проблема. Аби їі вирішити, студентам потрібні не тільки знання англійської мови, а й володіння великим обсягом різноманітних предметних знань, необхідних і достатніх для вирішення цієї проблеми. Крім того, студенти повинні володіти певними інтелектуальними, творчими, комунікативними вміннями.

До першого можна віднести вміння працювати 3 інформацією, з текстом англійською мовою (виділяти головну думку, вести пошук потрібної інформації в іноземному тексті), аналізувати інформацію, робити узагальнення, висновки.

Отже, для правильного використання методу проєктів потрібна значна підготовча робота, яка здійснюється в цілісній системі освіти у ЗВО, а не тільки в навчанні англійській мові.

Плануючи роботу з навчальним проєктом з іноземної мови, необхідно враховувати такі ключові умови:

- тематика навчальних проєктів може стосуватися як країни, мова якої вивчається, так $\mathrm{i}$ місця проживання студентів, що виконують цю роботу;

- студентів необхідно спрямовувати на порівняльний аналіз, зіставлення певних подій, фактів 3 життя представників різних національностей і країн, підходів до вирішення тих чи інших проблем;

- проблема, яка пропонується студентам, формулюється у такий спосіб, щоб спрямувати їх на включення автентичних джерел інформації;

- оформлення проєкту має бути цікавим і таким, що запам'ятовується;

- тематику проєктів слід вибирати відповідно до інтересів студентів;

- студентів необхідно спрямовувати до залучення інформації з різних сфер знань і дисциплін (Фатеева і Канатникова, 2013).

Якщо говорити про використання методу проєктів в практиці навчання англійської мови, то, безперечно, найбільший інтерес представляють міжнародні телекомунікаційні проєкти. Саме такі проєкти дають змогу вирішити найскладніше i, водночас, найсуттєвіше для методики завдання - створення мовного середовища та створення на його основі потреби у використанні англійської мови на практиці. Глобальна мережа Інтернет створює умови для отримання необхідної студентам і викладачам англійської мови інформації, що знаходиться в будь-якій точці земної кулі.

Будь-який користувач, з можливістю підключитися до мережі Інтернет, має можливість підібрати список літератури, наприклад, з бібліотечного каталогу Бібліотеки Конгресу США, отримати у свою скриньку потрібний матеріал, провести пошук статті, репортажу, іншої необхідної інформації з найрізноманітніших джерел англійською мовою. Ця інформація є автентичною і, працюючи з нею, можна отримати необхідні дані з проблеми, над якою в цей час працює група студентів у межах проєкту.

Однак в процесі реалізації методу проєктів необхідно брати до уваги можливість виникнення певних труднощів, наприклад:

1. Наявність певних психологічних проблем у студентів, які вважають за краще працювати самостійно, а не в групі. У подібних ситуаціях студенти не можуть правильно і адекватно планувати й організовувати спільну діяльність, тому їм слід пропонувати 
індивідуальні проєктні завдання, в роботі над якими вони матимуть можливість проявити свої здібності в психологічно сприятливих умовах.

2. Тримати в полі зору діяльність кожного студента над проєктом вдається не у всіх ситуаціях, особливо якщо мова йде про групові довгострокові проєкти, в яких задіяна значна кількість учасників.

3. Проєктний метод вимагає наявності певних знань і умінь у студентів, необхідних для виконання подібних видів роботи. Зокрема, таких, як уміння працювати в колективі, займатися пошуком і відбором необхідної інформації, розподіляти ролі, планувати навчальну діяльність, застосовувати творчий потенціал, успішно демонструвати результати проєктної роботи.

4. Недостатня підготовленість викладача до проєктних форм роботи, незнання основних вимог щодо організації та проведення подібних заходів, принципів і характеристик цього методу.

5. Складність планування певної серії занять і консультацій з проєкту, що пов’язано 3 низкою операцій і етапів роботи, значною кількістю оброблюваної інформації і учасників проєктної діяльності, труднощами щодо встановлення тимчасових меж і термінів.

6. Незвичність такої форми роботи в освітніх установах.

Такі труднощі особливо актуальні для тих викладачів, які зазвичай застосовують традиційні форми роботи на заняттях, не приділяючи належної уваги розвитку творчого потенціалу студентів у контексті навчання іноземної мови.

Для майбутнього фахівця знання іноземних мов у поєднанні 3 проєктною діяльністю є основними. Отже, необхідно переглянути процес навчання іноземним мовам 3 таких позицій, аби студенти ще на молодших курсах навчалися розвивати ключові вміння й компетенції, пов’язані з їхньою майбутньою професією.

Зважаючи на високі вимоги до сучасних фахівців, перед студентами ставляться нові комунікативні завдання, які вирішуються 3 точки зору іноземної мови. Ці завдання полягають у розвитку комунікативної іншомовної компетенції, розширенні світогляду, розвитку критичного мислення, розвитку вмінь здійснювати пошук, користуючись світовими інформаційними ресурсами, активної участі в освітньому процесі, що включає різноманітні сучасні методи навчання.

Висновки і перспективи подальших розвідок. Оскільки навчання іноземної мови - це комунікативна діяльність студентів, тобто практичне володіння іноземною мовою, а завдання викладача - активізація діяльності кожного студента, створення ситуації для творчої активності кожного в процесі навчання, то використання нових інноваційних технологій не тільки оживляє освітній процес та відкриває великі можливості для розширення освітніх меж, а й містить у собі величезний мотиваційний потенціал та сприяє принципам індивідуалізації освітнього процесу.

У сучасній системі вищої освіти метод проєктів застосовується як компонент системи освіти і є такою організацією самостійної діяльності студентів, яка спрямована на вирішення будь-якої проблеми, на досягнення певного результату. Проєктна діяльність студентів орієнтована на розкриття особистості, розвиток інтересу до освітньої діяльності, розвиток інтелектуальних, творчих здібностей в процесі вирішення будь-якої проблеми.

Перспективи подальших досліджень вбачаємо у пошуку способів вирішення труднощів реалізації проєктної методики у викладанні іноземної мови в закладах вищої освіти. 


\section{СПИСОК ВИКОРИСТАНИХ ДЖЕРЕЛ}

Зембатова, Л. и Бтемирова, Р.(2008). Организаиия и планирование самостоятельной работы студентов. Владикавказ: СОГПИ. 44 с.

Бтемирова, Р. (2012). Метод проектов - важнейшая составляющая в современном обучении математике. Современные технологии в образовании. Т.1, № 12. С. 33-38.

Комаровский, Б. (1969). Русская педагогическая терминология. Теории и история. Москва: Просвещение. 312 с.

Кримський, С. (2003). Проект і проектування у сучасній цивілізації. Метод проектів: традичії, перспективи, життєві результати: Практико-зорієнтований збірник. Київ: Департамент. С.6-15.

Дьюи, Дж. (1922). Школа будущего. Пер. Ландсберг. Изд. 2-е. Берлин: Госиздат. 179 с.

Вентцель, К. (1923). Новые пути воспитания и образования детей. Москва: Земля и фабрика. $149 \mathrm{c.}$

Новиков, А. и Новиков, Д. (2004). Образовательный проект (методология образовательной Деятельности). Москва: Эгвес. 120 с.

Фатеева, И. и Канатникова, Т. (2013). Метод проектов как приоритетная инновационная технология в образовании. Молодой ученый. №1. С. 376-378.

\section{REFERENCES}

Zembatova, L. \& Btemirova, R. (2008). Organizatsuya i planirovanie samostoyatelnoi raboty studentov. [Organization and Planning of Students' Independent Work]. Vladikavkaz: SOGPI. 44 s. (in Russian).

Btemirova, R. (2012). Metod proektov - vazhneishaia sostavlyayushchaya v sovremennom obuchenii matematike. [The Project Method - the Most Important Component in Modern Teaching of Mathematics]. Sovremennye tekhnologii v obrazovanii. T.1, No 12. S. 33-38. (in Russian).

Komarovskii, B. (1969). Russkaya pedagogicheskaya terminologiya. Teorii i istoriia. [Russian Pedagogical Terminology. Theories and History]. Moskva: Prosveshchenie. 312 s. (in Russian).

Krymskyi, S. (2003). Proekt i proektuvannia u suchasnii tsyvilizatsii. [Project and Project Designing in Modern Civilization]. Metod proektiv: tradytsii, perspektyvy, zhyttievi rezultaty: Praktyko-zoriientovanyi zbirnyk. Kyiv: Departament. S.6-15. (in Ukrainian).

Diui, Dzh. (1922). Shkola budushchego. [School of Future]. Per. Landsberg. Izd. 2-e. Berlin: Gosizdat. 179 s. (in Russian).

Venttsel, K. N. (1923). Novye puti vospitaniya i obrazovaniya detei. [New Ways of Upbringing and Education of Children]. Moskva: Zemlya i fabrika. 149 s. (in Russian).

Novikov, A. \& Novikov, D. (2004). Obrazovatelnyi proekt (metodologiya obrazovatelnoi Deyatelnosti). [Educational Project (Methodology of Educational Activity)]. Moskva: Egves. 120 s. (in Russian).

Fateeva, I. \& Kanatnikova, T. (2013). Metod proektov kak prioritetnaya innovatcionnaya tekhnologiya v obrazovanii. [Project Method as a Priority Innovative Technology in Education]. Molodoi uchenyi. No1. S. 376-378. (in Russian). 


\title{
INNOVATIVE TECHNOLOGIES IN EDUCATION: PROJECT METHOD IN THE STUDY OF FOREIGN LANGUAGES
}

\author{
Liudmyla Nykonorova \\ Senior Lecturer at the Department of Foreign Languages, \\ National Academy of Statistics, Accounting and Audit, \\ Kyiv, Ukraine \\ ORCID: 0000-0003-1848-1714 \\ e-mail: lipotselyi@gmail.com
}

\begin{abstract}
As the new socio-economic conditions for the development of the world community have led to a change in the requirements for professional training, the education system faces the problem of qualitative training of competitive and competent specialists of a new level, focused on personal self-improvement and professional growth.

That is why higher educational institutions try to solve new tasks, such as search and implementation of effective educational technologies, mechanisms and ways of teaching. One of such mechanisms is the project method, which, as a pedagogical technology, includes a set of research, search and problem methods. The method of projects is a set of techniques, actions of students and the teacher in their specific sequence to achieve the given task, i.e. to solve a specific problem that is meaningful to students and is designed as the final product. The main purpose of this method is to provide students with the ability for independent knowledge acquiring in the process of solving practical tasks or problems, which requires the integration of knowledge from different subjects. In English language teaching, the project method enables students to use the language in real-life situations, which undoubtedly contributes to a better acquisition and consolidation of foreign language skills. The article outlines the key conditions that should be taken into account when planning a foreign language learning project. In addition, the author proposes to pay more attention to international telecommunication projects, since such projects allow solve the most difficult and, at the same time, the most essential task for methodology - creating a linguistic environment and on its basis creating the need to use English in practice. The article also lists the difficulties that may arise when using this method.
\end{abstract}

Keywords: innovative technologies, project method, innovations in higher educational institutions, teaching a foreign language, project, method, methodology.

Стаття надійшла до редакиії 05.02.2020 p. 